\title{
Formation and development of fodder production in Ukraine
}

\section{Petrychenko V. ${ }^{1}$, Korniychuk O. ${ }^{2}$, Zadorozhna I. ${ }^{3}$}

Institute of Feeds and Agriculture of Podillia NAAS, Prospect Yunosti, 16, Vinnytsia, 21100, Ukrai-ne; email: ${ }^{1}$ petrichenko.vasil@gmail.com, ${ }^{2}$ o.kornychuk@ukr.net, ${ }^{3}$ i.s.zadorozhna@ukr.net

The purpose. To highlight the formation and development of the scientific support of feed production industry in Ukraine, contribution of the Institute of Feeds and Agriculture of Podillia of NAAS to the development of feed production as a science, to generalize the main scientific achievements. Methods. On the basis of materials from periodicals and monographs, the formation and development of feed production as a science was analyzed. To solve the problem, general research methods (analysis, synthesis) and historical methods (problem-chronological) were used. Results. The development of scientific support of feed production industry in Ukraine was displayed through the prism of researches on these issues. The main achievements of the Institute of Feeds and Agriculture of Podillia of NAAS in the development of scientific approaches to feed production were analyzed. Conclusions. Further development of the feed production industry as a science should be based on innovative principles under improvement of the optimal structure of areas under forage and grain crops; enhancement of the breeding research in the direction of increasing the adaptive capacity of new varieties to adverse environmental factors and developing modern competitive varieties of cultivation technologies; development of new and improvement of current intensive technologies for the cultivation of perennial grasses, maize for silage and grain, legume-grain crops and soybean; improvement of integrated plant protection; biologization of technological processes of growing forage crops in specific natural and climatic zones under effective eco-friendly use of soil fertility, improvement of the technologies of harvesting, storage and utilization of feeds and monitoring of feedstock and feed quality.

Key words: feed production, scientific research, forbvgage crops, feeds, variety, breeding, tech-no-logy. https://doi.org/10.31073/agrovisnyk201811-08

Introduction. The basis of Ukraine's food security is a highly efficient and balanced agriculture that is able to provide food production in sufficient amount to meet the needs of the country's population and to form the required powerful export potential. Livestock breeding is one of its most important branches, and its sustainable development is impossible without a reliable feed base. The leading role in its formation is occupied by feed production.

The purpose of the research is to highlight the formation and development of the scientific support of feed production industry in Ukraine, contribution of the Institute of Feeds and Agriculture of Podillia of NAAS to the development of feed production as a science, to generalize the main scientific achievements.

Materials and methods. Based on the materials of periodicals and monographs, the formation and development of feed production as a science was analyzed. To solve the problem, general research methods (analysis, synthesis) and historical methods (problem-chronological) were used.

Research results. Scientific foundations of feed production in Ukraine have been developing in the course of searching for scientific thoughts, new approaches and research methods. In particular, for almost a century, they have progressed from the first studied and described forage grasses, fodder root crops, the first use of fallow under forage grasses and other crops, field research methods and a new methodology for conducting research, developed green conveyors for different types of farm animals to obtaining green feeds both in the feed and field crop rotations due to post-harvest and post-cut crops, development of agricultural machinery for the cultivation of perennial and annual grasses, their mixtures, feed crops, techniques of effective application of fertilizers, intensification of feed production due to application of chemicals and search for the ways of intensification of feed crop rotations.

Due to the necessity to solve the problem of feeds and feed protein, the Ukrainian Research Institute of Feeds was established in Vinnitsa in 1973 (according to the order No 158 of the USSR Ministry of Agriculture of May 14, 1973), and it started to perform the functions of the chief state scientific center for feed production. The Institute was also aimed to operate as a methodological and coordination center for the fundamental and applied research on feed production and use. 
The Institute carried out researches in such areas as the study of the productivity of various feed crops and their mixtures in post-cut and post-harvest crops, research of intermediate winter crops (V.I. Hudyma, D.P. Belichenko); study of the influence of various cover crops on the yield of perennial legumes and grasses (H.P. Kvitko); study of the productivity of double-crop mixtures of annual grasses (M.M. Merezhko); breeding and seed production of feed crops (K.I. Khrestetskyi, A.F. Shamrai); examination of the effect of fertilizers on the productivity and quality of fodder beet varieties (B.O. Rudnytskyi); development of sciencebased high-yield feed crop rotation for large livestock farms and complexes of cattle (H.P. Kvitko, Y.Y.Panasiuk, D.P. Belichenko).

During 1981-1985 the Institute coordinated scientific researches and it was the central methodological, scientific and organizational center of Ukraine for implementation of the Target Complex Program 041 "Formation and introduction of high-yield varieties of feed crops, development and mastering of the advanced technological processes for production, processing, harvesting and storage of feeds" and the AllUnion scientific and technical program 0.51.04 "Improve the current, develop and introduce new technologies for the production, storage and processing of rough coarse and juicy feeds in the zones of the country on the basis of complex mechanization, plant protection, intensive varieties of feed crops, which will ensure an increase in the yields of high-quality feeds per hectare" and the Republican program "Agrocomplex" (1986-1990).

As a result, feed production became a specialized branch, which was aimed at providing scientific support. In 1989, the team of scientists of the Institute (A.O. Babych, M.F. Kulyk, V.V. Khimich, A.I. Ovsienko) was awarded the Prize of the Council of Ministers of the USSR in the Field of Science and Technology for the development and introduction into production of energy-saving technology of harvesting, post-harvest processing, storage and use of wet grain and corncobs for cattle feeding.

The Institute of Feeds coordinated research work on feed production of 42 scientific establishments of the republic, including 12 research institutes, 10 universities, 18 regional and 2 zonal research stations.

The leading role of the Institute in solving the problem of providing livestock with full-value feeds to increase the production of meat, dairy and other food products and satisfy the demand of the population was noted in the Resolution of the Council of Ministers of USSR No. 73 of April 12, 1990 "On the work of the Ukrainian Scientific Research Institute of Feeds aimed to solve the problem of livestock supply with highvalue feeds in the republic".

The Ukrainian Research Institute of Feeds, together with other scientific institutions, "The concept of development of feed production at the farms of the USSR in 1991-1995 and by 2005", which was developed considering scientific achievements of the Ukrainian Research Institute of Feeds, was approved.

In 1990, when the Ukrainian Academy of Agrarian Sciences (UAAS) (currently NAAS) was established, a scientific-methodical and coordination center on the problems of the agro-industrial complex and agroecology was formed in Ukraine. UAAS approved the main organizations responsible for the implementation of the programs. Among them there was the Ukrainian Research Institute of Feeds of UAAS, which remained the leading institution for feed production in Ukraine for implementation of the project "Feeds and Feed Protein" of the scientific-and-technical program "Food-95".

In 1992, according to the resolution of the Presidium of UAAS from January 29, 1992, the Ukrainian Research Institute of Feeds was renamed into the Institute of Feeds of the UAAS, and since 2010, when the Ukrainian Academy of Agrarian Sciences achieved the status the National, the Institute of Feeds of NAAS became the chief institution of the Scientific and Methodological Center "Feed Resources". In 2012, according to the order of the National Academy of Agrarian Sciences of Ukraine "On the Renaming of the Institute of Feeds of NAAS" No. 160 of July 11, 2011, the Institute received its current name, i.e. the Institute of Feeds and Agriculture of Podillia of NAAS. Nowadays, its network includes the State Enterprise "Scientific Innovation and Technology Center of the Institute of Feeds of NAAS", Ternopil and Khmelnytskyi State Agricultural Research Stations.

During the years of its functioning, the Institute has been headed by Academician of the All-USSA Lenin Academy of Agricultural Sciences Illia Proskur (1973-1980); Doctor of Agricultural Sciences, Professor, Academician of NAAS Anatolii Babych (1980-2001); Doctor of Agricultural Sciences, Professor Leonid Podobed (2001-2002); Doctor of Agricultural Sciences, Professor, Academician of NAAS Vasyl Petrychenko (2002-2011); Candidate of Agricultural Sciences Oleksandr Korniichuk (2011 - present). 
At the beginning of Ukraine's state independence, there took place global processes of transformation of the national economy from the planned to the market economy, in particular, the agrarian reform.

The Institute and research institutions coordinated by it had to solve the problems related to the implementation of the program on stabilization and development of livestock production, which was possible only on the basis of innovative principles under the improvement of the optimal structure of areas under fodder and grain-forage crops; strengthening of breeding research through the enhancement of the adaptive capacity of new varieties to adverse environmental factors and development of modern, competitive varietal cultivation technologies; development of new and improvement of the current intensive technologies for the cultivation of perennial grasses, corn for silage and grain, leguminous crops and soybean; improvement of integrated plant protection; biologization of the technological processes of growing fodder crops in specific natural and climatic zones with effective eco-friendly use of soil fertility.

Throughout its 45-year history, the Institute of Feeds and Agriculture of Podillia has got many scientific achievements in various areas of feed production. They include the development of high-yield varieties of perennial grasses with the increased productivity potential, prolonged productive longevity in pure and mixed crops, which are suitable for hay and hay-pasture use; competitive varieties and hybrids of fodder grainforage and leguminous crops [1-3]; development of technologies of their cultivation for seeds. This is the result of the efficient work of V.D. Buhaiov, V.S. Mamalyha, S.P. Shelest, S.F. Antoniv, Y.S. Bekhatskyi, L.P. Shcherbyna, T.V. Lilyk, V.M. Bortnovskyi, M.I. Kondratenko and others. Over 60 varieties of legume and cereal grasses were included in the State Register of Plant Varieties of Ukraine, in particular, alfalfa varieties Regina, Syniukha and Rosana; red clover varieties Anitra, Sparta, Politanka and Tina; alsike clover varieties Levada and Viliia; white clover variety Danaia; bird's-foot trefoil varieties Ajax and Ant; sweet clover variety Enei; annual westerwolds ryegrass variety Tyverskyi and Oreol, perennial ryegrass varieties Obrii and Ruslana, Aitera; tall fescue variety Ludmyla; meadow fescue variety Dibrova; red fescue varieties Yanka and Agata; timothy varieties Dibrova and Aira; sheep's fescue variety Zabava; Festuca tenuifolia Sibth variety Barva; Fairway Crested Grass variety Petrovskyi; pea varieties Elegant, Svitiaz, Atanas and Grant; white mustard varieties Oslava and Karolina; winter triticale varieties Polianske, Polovetske, Bohodarske and others.

Some varieties are being tested by the State Variety Test, including alfalfa varieties Radoslava, Amaha, Rodena and Ramina, winter triticale variety Desiatynne, fairway crested grass variety Hlobinskyi, sheep's fescue (all varieties) variety Skifska, pea variety Alan, sheep's fescue (all varieties) variety Marbela, Italian ryegrass variety Ulych, red top (white) variety Sabina.

There were produced highly productive varieties of soybean, faba bean and beans with improved indicators of seed quality (increased content of protein, fat and reduced content of trypsin inhibitors, urease activity), increased biological nitrogen fixation ability [4,5]. This is the result of creative work of A.O. Babych, V.F. Petrychenko, S.V. Ivaniuk, T.O. Bolokhovska, I.V. Temchenko, S.I. Kolisnyk, S.Y. Kobak, A.A. Lekhman, S.I. Babii and many other scholars. Independently and jointly with other research institutes of the Academy, the soybean varieties were produced and registered in the State Register of Plant Varieties suitable for distribution in Ukraine, including soybean varieties Cherniatka, Podilska 1, Podolianka, Prykarpatska 81, Krasa Podillia, Agat, Podilska 416, Artemida, Oksana, Anatoliivka, Valiuta, Prykarpatska 96, Oriana, Zolotysta, Femida, Yuvileina, KiVin, Omega Vinnytska, Monada, Smolianka, Hoverla, Vinni, Vezha, Khutorianochka, Kniazhna, Diadema Podillia, Millenium, Triada, Samorodok; faba bean varieties Orion, Bilun, Vizyr, Peremozhets, Pikantni; and bean varieties Slavia, Ros, Galactyka. Soybean varieties Azymut and Pallada are being tested by the State Variety Test.

The priority of scientific approaches to selection was proved by 38 author's certificates and patents of Ukraine for soybean, faba bean and bean varieties.

Based on the analysis of the bioclimatic potential, socio-economic and social aspects of the development of the agroindustrial complex of the regions by the scientists of the Institute (V.F. Petrychenko, A.O. Babych), the soybean zone of Ukraine was determined. In time, it was transformed into a soybean-and-corn belt.

Considerable attention is paid to selection of spring barley, winter and spring rape, spring vetch (P.K. Dovhaniuk, N.H. Avramchuk, P.I. Vyshnevskyi, V.I. Aralov, N.I. Humenna, O.V. Korniichuk, V.O. Doroshchuk, L.B. Betsenko) [6, 7]. A great number of varieties were produced and included in the State Register of Plant Varieties of Ukraine, including winter rape varieties Svitoch, Horizont, Bazhanyi, Ranok 
Podillia, Chornyi Veleten, Antariia, Hipanis; spring rape varieties Mariia, Oksamyt, Aira; spring vetch varieties Vinnytska 30, Vinnytska 2, Podilska 18, Prybuzka 19, Margaryta, Podilska 9, Ariadna, Viarika, Svitlana, Iryna, Liliana, Vladyslava; Yelizaveta, Nadiia Podillia, Pivdennobuzska; spring barley varieties Lotos, Skif, Vinnytskyi-28, Lofant, Nezabudka, Nabat, Oberih, Svarog, Armaks, Barvystyi, Tiver, Aristei, Ayris.

In 2014 the State Prize of Ukraine in the Field of Science and Technology was awarded to O.V. Korniychuk for his contribution to the formation of the balanced agroecosystems of the domestic winter wheat seed production.

A considerable number of researches is carried out on the selection of new or rare fodder crops. A number of varieties were produced and included in the State Register, including amaranth varieties Atlant, Aztek, Orkhideia and Palmira; Alexandrian clover variety Oriana; open clover variety Diana; wheat grass intermidiate variety Khors; meadow brome variety Boian; slender wheat grass variety Columb.

There have been developed adaptive varietal technologies for growing soybean and other leguminous crops for different soil and climatic conditions of the regions; soybean production technologies on the dry soils and irrigated lands of Ukraine; technology of soybean production in Ukraine under no-till technology [8]. Short crop rotations with optimal ratios of high protein (soybean) and grain forage (maize, barley, spring, wheat wheat) crops; resource-saving technologies of growing seeds of legume and cereal grasses have been investigated.

Introduction of such technologies has significantly increased grain production of leguminous crops and soybean, their sale on the domestic market, which has made it possible to meet the domestic demand for high-protein ingredients and to generate export resources as well.

The Institute has developed eco-friendly technologies of growing perennial legume grasses, which guarantee stable yields of high protein feeds and ensure sustainable productivity increase by $30-35 \%$ irrespectively of meteorological factors; the system of conveyor production of green feeds on the basis of new species and varieties of annual crops, which ensures continuous flow of plants for haymaking and silage, has been improved; the energy-saving technology of growing maize hybrids of different maturity is developed in pure and mixed crops with high protein crops, which provides a yield of 12-14 t/ha of dry matter and an increase in protein nutritional value by $25-30 \%$. Scientific developments have been tested in agricultural formations of different ownership forms of Vinnytsia, Kyiv, Khmelnytskyi and others regions.

When solving urgent issues of restoration and preservation of soil fertility, production of eco-friendly products that are safe for human health, the physiological and biochemical, microbiological and molecular genetic features of the formation and functioning of the symbiotic systems "legume plants - microorganisms" [9] were studied at the Institute. The generalized results of fundamental and applied research carried out during 1991-2011 made a significant scientific contribution, namely the joint creative collaboration "Legume and Rhizobial Systems in Modern Agriculture". Its application promoted high yields of eco-friendly products and it was awarded with the State Prize of Ukraine in the Field of Science and Technology in 2012 (V.F. Petrychenko, A.O. Babych, S.V. Ivaniuk).

In recent years the following issues have been studied: theoretical substantiation of the processes of formation of photosynthetic and symbiotic apparatus of perennial legume grasses; development of the models of agrophytocenoses of annual crops for harvesting various kinds of feeds; development of the ways aimed to increase the yield and quality of green matter and corn grain for production of silage with a dry matter content of $28-30 \%$ and fiber content of $22-23 \%$ for efficient feeding of high-yield cows, and on their basis a resource-saving cultivation technology for the production of eco-friendly feeds; development of scientific principles for assessing agrotechnologies by bio-diagnostic indicators and measures for improving the ecological status of agrocenoses (N.Y. Hetman, H.P. Kvitko, B.O. Rudnytskyi, Y.Y. Panasiuk, V. I. Barvinchenko, M. M. Merezhko, I.F. Pidpalyi, I.Y. Pelekh, V.V.Kyforuk and others) [10, 11].

As for the fodder grass cultivation, the achievements of the Institute include energy-saving technology for the grassing and use of the cultivated pastures with the use of green mature as the basic fertilizer; ecologically safe technologies of radical and surface improvement of natural grasslands; resource-saving technology of grassing slopes with the complex use of annual crops phytomeliorants; environmental technology for the creation of phytocoenotically active perennial grasslands on the slopes, which formerly were arable lands, using cruciferous and leguminous cover crops; technology of creation and use of highyielding cultivated pastures with grasses of different maturity for dairy herds on the irrigating lands; 
technology of development of drained lands with saline soils of the eastern Forest-Steppe; technology of conveyor production of green mass on perennial grass stands for the harvesting of hay and haylage; technological methods of growing low-spread fodder crops on different types of grasslands; technology of creating perennial grasslands using new varieties of legumes and short grasses having different regrowth intensity (P.S. Makarenko, S.H. Nazarov, S.I. Osetskyi, K.P. Kovtun, Y. A. Veklenko and others) [12-14].

Scientists of the Institute have conducted a weed monitoring of agrocenoses of feed and grain-forage crops in the right-bank Forest-Steppe of Ukraine and created a database of potential weed infestation of arable lands and species composition of weeds. Features of the formation of weed groups in modern agrocenoses of feed and grain-forage crops have been specified. Economic thresholds for weed damage and thresholds for herbicide application in fodder beet, alfalfa, clover, corn, cereals, soybean, spring vetch, faba beans and blue lupine have been established for the first time. Eco-friendly systems of integrated weed control in corn, soybean, grain-forage, legume crops and in short crop rotations have been developed. The research results in this area have been represented at the international symposia on Weed Science (V.P. Borona, V.S. Zadorozhnyi, V.V. Karasevych) [15, 16].

New technologies and implements for gathering, processing and using feeds have been developed; more than 10 preservatives for the storage of wet corn grain and other cereal crops, harvesting and storage of haylage from legume grass mixtures, fresh pulp have been patented and introduced; methods of neutralizing anti-nutrients in soybean and lupine grain, the technology of harvesting and storage of pressed hay and haylage in rolls using non-belt press-pickers, improved technological processes of harvesting of feeds from grasses during the operation of machine-tractor units on constant technological tracks have been improved; utilization of wastes of alcohol and breweries, post-caseinic buttermilk, products in the production of biodiesel for livestock feeding, as well as saponite-based feed additives for farm animals and poultry have been introduced into production (M.F. Kulyk, S.Y. Olishynskyi, O.K. Stasiuk, V.P. Zhukov, A.I. Ovsienko, I.M. Velychko, O.M. Kurnayev, Y.A. Obertiukh) [17].

The Institute of Feeds and Agriculture of Podillia of NAAS has got a certified in accordance with the requirements of the State Standards of Ukraine ISO 10012:2005 Laboratory for Assessing the Quality of Feedstock and Feed Safety, Quality Indicators of Crop Grain and Seed, which uses modern methods of liquid and gas chromatography, atomic absorption spectrometry, flame photometry, production and testing complex for the determination of nutritional value of feeds and diets of farm animals and poultry taking into account the needs of animals, availability of nutritious elements and their changeability (L.P. Chornolata, T.N. Halemba, L.S. Prokopenko, V.K. Yurchenko, H.F. Yurchenko, O.Y. Palats, R.V. Olonicheva).

Scientists of the Institute of Feeds and Agriculture have developed "The Concept of Feed Production Development in Ukraine 2025".

In the framework of the international programs, protocols and agreements, the Institute of Feeds and Agriculture of Podillia of NAAS collaborates with foreign scientific institutions, conducts joint researches with the interested companies, associations of CIS countries, the USA, Lithuania, Serbia, Hungary, the Netherlands, Germany, and Poland. The Institute of Feeds and Agriculture of Podillia of NAAS actively participates in the work of the international cluster "Agro-Dniester" within the Program of Territorial Cooperation of the Countries of the Eastern Partnership Moldova-Ukraine, which promotes the development of new trade ties, participation in the international scientific programs, exchange of experience, and introduction of innovative achievements.

In general, over 45 years of existence, about 230 books, 85 interdepartmental thematic scientific collections of papers "Feeds and Feed Production" were published by the scientists of the Institute of Feeds and Agriculture of Podillia of NAAS. 200 patents and author's certificates for inventions and utility models have been received. The breeders of the Institute have produced and submitted to the State Variety Testing nearly 160 varieties and hybrids of forage, legume, grain and other crops, and almost 150 of them were included in the State Register of Plant Varieties that are suitable for distribution in Ukraine and protected by the appropriate certificates and patents. Scientists of the Institute are co-authors of more than 20 plant varieties produced by other institutions.

The Institute provides training of the scientific staff through post-graduate studied for PhD and Doctor's degree in such specialties as Agronomy, Feed Production and Grass Farming, Breeding and Seed 
Production, Plant Growing, Animal Feeding and Feed Technology. There is a specialized Scientific Council for the thesis defense.

The staff of the Institute implements 14 state scientific and technical programs of NAAS and a number of projects of the Ministry of Agrarian Policy and Food of Ukraine and, as the chief institution of the scientific and methodical center for the implementation of the program of scientific research "Feeds and Feed Protein", "Scientific Basis of the Feed Production and Use for Competitive Livestock Production 2016-2020", coordinates activities of 29 institutions of the NAAS system, which is aimed at solving urgent goals of feed production, development of innovations and their wide introduction into production, which will help to obtain competitive livestock products and ensure the country's food security.

\section{Conclusions}

Of scientific support of the feed production industry in Ukraine is shown through the prism of the research institutions of the Academy, which have conducted research in this direction, in particular the Institute of Feeds and Agriculture of Podillia of NAAS.

Further development of the feed production industry as a science should be based on innovative principles under the improvement of the optimal structure of areas under forage and grain crops; enhancement of the breeding research in the direction of increasing the adaptive capacity of new varieties to adverse environmental factors and developing modern competitive varietal cultivation technologies; development of new and improvement of current intensive technologies for the cultivation of perennial grasses, maize for silage and grain, legume-grain crops and soybean; improvement of the integrated plant protection; biologization of the technological processes of growing forage crops in specific natural and climatic zones under effective eco-friendly use of soil fertility, improvement of the technologies of harvesting, storage and utilization of feeds and monitoring of feedstock and feed quality.

\section{References}

1. Buhaiov V., Horenskyy V., Liatukienè A. (2018). The response of Medicago sativa to aluminium toxicity under laboratory and field conditions. Zemdirbyste-Agriculture. Akademija, Kèdainiai distr., Lithuania. V. 105. No. 2. P. 99 - 104. (Scopus).

2. Buhaiov V.D., Buhaiov V.V., Smulska I.V. (2017). Vykorystannia sortiv maloposhyrenykh zlakovykh trav yak chynnyk pidvyshchennia produktyvnosti kormovykh uhid. [Use of varieties of uncomplicated cereal grasses as a factor in increasing the productivity of forage lands]. Sortovyvchennia ta okhorona prav na sorty roslyn. T. 13, No. 1, P. 89 - 94. [In Ukrainian].

3. Buhaiov V.D., Horenskyi V.M. (2017). Ekolohichna plastychnist kolektsiinykh zrazkiv liutserny posivnoi za kormovoiu ta nasinnievoiu produktyvnistiu $v$ umovakh pidvyshchenoi kyslotnosti gruntu. [Ecological plasticity of collectible samples of alfalfa for sowing and seed productivity in conditions of high acidity of the soil]. Selektsiia i nasinnytstvo. No 112. P. 17 - 24. [In Ukrainian].

4. Babych. A.O., Babych-Poberezhna A.A. (2008). Selektsiia i rozmishchennia vyrobnytstva soi v Ukraini. [Selection and placement of soybean production in Ukraine]. Vinnytsia: FOP Danyliuk. 216 p. [In Ukrainian].

5. Babych. A.O., Ivaniuk S.V., Babii S.I. (2013). Osnovni rezultaty selektsii bobiv kormovykh i kvasoli zvychainoi v I nstytuti kormiv ta silskoho hospodarstva Podillia NAAN. [The main results of breeding of broad beans and beans in normal And Institut of feed and agriculture of Podillya NAAS]. Visnyk ahrarnoi nauky. Spetsialnyi vypusk. P. 25 - 27. [In Ukrainian].

6. Korniichuk O.V., Honchar T.M., Fomenko L.O. et al. (2013). Selektsiia ripaku: dosiahnennia i perspektyvy. [Rape Selection: Achievements and Prospects]. Visnyk ahrarnoi nauky. Spetsialnyi vypusk. P. 36 - 38. [In Ukrainian].

7. Aralov V.I., Aralov O.V., Aralova T.S. et al. (2013). Vykhidnyi material, metody i rezultaty selektsii horoshku (vyky yari). [Source material, methods and results of selection of peas (wicks of yarrow)]. Visnyk ahrarnoi nauky. Spetsialnyi vypusk. P. 39 - 41. [In Ukrainian].

8. Petrychenko V.F., Lykhochvor V.V., Ivaniuk S.V. et al. (2016). Soia: monohrafiia. [Soya: monograph]. Vinnytsia: «Dilo». 400 p. [In Ukrainian]. 
9. Petrychenko V.F., Kobak S.la., Chorna V.M. et al. (2018). Formuvannia azotfiksuvalnoho potentsialu ta produktyvnosti sortiv soi selektsii Instytutu kormiv ta silskoho hospodarstva Podillia. [Formation of nitrogen fixing potential and productivity of soybean selection varieties of Podillya Institute of forage and agriculture]. Mikrobiolohichnyi zhurnal.No 5. P. 63 - 75. [In Ukrainian].

10. Hetman N.Ia., Kvitko H.P. (2013). Ahrobiolohichne obgruntuvannia resursooshchadnykh tekhnolohii vyroshchuvannia fitotsenoziv bahatorichnykh ta odnorichnykh kormovykh kultur $\mathrm{u}$ polovomu kormovyrobnytstvi. [Agrobiological substantiation of resource-saving technologies of growing phytocoenoses of perennial and one-year fodder crops in field fodder production]. Visnyk ahrarnoi nauky. Spetsialnyi vypusk. P. 72 - 77. [In Ukrainian].

11. Petrychenko V., Veklenko Y. (2010). Annual pastures on arable lands - prospect of their fast involving in forage production. Biotechnology in Animal Husbandry. Serbia. Is 26. P. $371-379$.

12. Petrychenko V.F., Kurhak V.H. (2013). Kulturni sinozhati ta pasovyshcha Ukrainy. [Cultivated grasslands and pastures of Ukraine]. Kyiv: Ahrarna nauka. 432 p. [In Ukrainian].

13. Petrychenko V., Zadorozhny V., Veklenko Y. (2011). State and prospects of the use of natural grasslands in Ukraine. Grassland farming and land management systems in mountain regions. Book of abstracts 16th Symposium of the European Grassland Federation. Austria. P. 111.

14. Petrychenko V.F., Korniichuk O.V., Veklenko Yu.A. (2018). Stalyi rozvytok lukopasovyshchnoho kormovyrobnytstva $v$ umovakh zmin klimatu. [Sustainable development of on-farm fodder production in climate change]. Visnyk ahrarnoi nauky. No 6 (783). [In Ukrainian].

15. Zadorozhnyi V., Borona V., Petrychenko V. (2011). Weed harm and their chemical control in grain legume mixtures. Herbologia (A Weed Science for Weed Research and control). Bosnia and Herzegovina. V. 12. No 2. P. $31-34$.

16. Zadorozhnyi V.S., Borona V.P., Karasevych V.V. et al. (2013). Efektyvnist intehrovanoho kontroliu burianiv $v$ ahrotsenozakh silskohospodarskykh kultur. [Efficiency of integrated weed control in agricultural crops]. Visnyk ahrarnoi nauky. Spetsialnyi vypusk.P.72 - 77. [In Ukrainian].

17. Kulyk M.F., Zhukov V.P., Didorenko T.O. et al. (2018). Novi pryntsypy balansuvannia mineralnoho zhyvlennia diinykh koriv: monohrafiia. [New principles of balancing mineral nutrition of dairy cows: monograph]. Vinnytsia: FOP Rohalska I.O. 220 p. [In Ukrainian]. 